\title{
Melos, opsis, logos
}

\author{
Et memo om lyrikanalyse
}

\section{DAN RINGGAARD}

\section{Bristen}

Navnlig siden nykritikken har man viet digtets billedsprog en særlig opmærksomhed. I særdeleshed dekonstruktionen har fornyet denne nykritikkens retoriske interesse og således gjort den del af den formelle analyse, som har at gøre med troper og figurer, yderligere anvendelig i studiet af den litterære teksts betydning og betydningsdannelse. Derimod har det skortet på kvalificerede forsøg udi den anden del af den formelle lyrikanalyse, nemlig den musikalske, dvs. digtets rytme og klang. De to litteraturkritiske strømninger har trods en fælles affinitet for lyrik ikke kunnet gøre med metrikken (der udgør den rytmiske-halvdel af digtets musik), hvad de har gjort med retorikken. ${ }^{1}$ Hvis troper og figurer har en betydning, der på udsigelsens niveau kan tale skævt til eller midt imod temaet, hvorfor så ikke metrikken? Den er stadig mest ornatus for den analytiske betragtning en birolle billedsproget for længst er løst fra. Jeg vil begynde med et rids, der skal illustrere forarmelsen og strejfe et bud på at overstå den.

Allerede i 1919 er Valdemar Vedel i sin artikel „Meningsrytme “2 opmærksom på miseren. Han sammenfatter metrikkens mådelige meritter ved at citere metrikeren Ernst von der Recke for, at „man i Reglen i Verset bør sørge for, at noget støtter Rytmen og noget bryder den; Reglerne derfor lader sig ikke udtømme, i Principets Anvendelse ligger selve Kunstnerens Mesterskab“. „Den fuldstændigste Falliterklæring“, mener Vedel, og 
fortsætter: „Der opstilles et skema, men det meddeles samtidig, at Kunsten bestaar $i$, $i$ et passende, ukendt Forhold at overholde og at bryde det" (s. 268). Et halvt århundrede senere gentager Poul Borum kritikken i sin artikel "Meningsmetrik" ${ }^{\prime 3}$ nu rettet mod Ernst von der Reckes efterfølgere Arthur Arnholtz og Jørgen Fafner.

Vedel og Borum udfordrer metrikken med en anderledes rytmelære. Den klassiske metrik er deskriptiv; dog kan den række ind i fortolkningen ved at påpege afvigelser fra normen, med deraf følgende emfase på det afvigende, og i ældre udgaver kan den spekulere over bestemte rytmers art. Den kan understøtte og uddybe temaet, og således åbne et oplevelsesrum, der ellers er den metrisk ubehjælpsomme læser forment. Det samme kan siges om klanganalysen. Det er godt nok, men ikke nok. Her er det så, Vedel forsøger sig. Arbejder metrikken, som det fremgår af von der Recke-citatet, med en spænding mellem metrik og rytme, mellem versets tryk- eller længdetællende norm og så prosodien, forstået som prosarytme, sætter Vedel en tredje ry tme midt imellem:

... i virkelig inspireret Digtning er det utvivlsomt i Reglen et Stykke følelsesbetonet Forestillingsliv, som udformer sig i Ord og Ordforbindelser af en vis iboende Rytme, og ud af disse levende Meningsrytme-Satser udformer Verset sig. Allerførst - tænker jeg mig - nynner Sindsstemningen sig frem i en Lyd- eller Bevægelsesrække af et vist Tempo, med en vis Taktering, idet 2-3-4 Lyd grupperer sig sammen [...] paa denne nynnende Understrøm gynger der saa Ord eller Ordforbindelser frem, Lyd og Indhold i uløselig Enhed, der har en Rytme i sig, og disse bliver Motivet, hvorudaf Rytmemelodien udfolder sig. (s. 283)

I stedet for versefødderne fæstner Vedel sig ved rytmisk-imaginære ansatser til sprog. Kan man identificere dem, har man en rytme, der genererer mening, altså en meningsrytme. Det er den rytme, man ofte kan høre digtere læse op i, en rytme, der hverken grupperer ordene efter den prosodiske rytme, der anskueliggør meningen, eller efter metrikkens metronom, men på en helt tredje måde. ${ }^{4}$ At det sker i 1919 er ikke tilfældigt. Metrikken har nemlig ikke kun et problem med sin deskriptivitet, den er også 
truet af det frie vers. I det findes versefødderne højst som fragmenter, og den rytmiske spænding mellem metrik og rytme er afløst af én mellem netop prosodisk rytme og så denne tredje rytme, som jeg - af årsager der senere vil åbenbare sig - vil kalde oraklisk. Den orakliske rytme er også tilstede i metriske digte, men der er den et supplement og ikke et alternativ til metrikken. Vedel og Borum har altså ikke overflødiggjort den klassiske metrik; men de har hjulpet den litterære analyse af rytme ved at identificere den orakliske rytme. ${ }^{5}$

At deres anstrengelser har været forgæves, og at dét ikke bare skyldes en særlig type metrik, fremgår eksemplarisk af måden, hvorpå Morten Nøjgaard i Det litterære værk 6 endnu et kvart århundrede efter Borums artikel afslutter sin gennemgang af det, han kalder lyduniverset: „Hovedårsagen til den lyriske poesis magt over menneskesindet" findes i lyduniverset, og det "ville derfor ikke være urimeligt, om man anvendte det meste af digtanalysen til at undersøge netop dette forhold./ Alligevel lægges der næsten altid i vor europæiske tradition størst vægt på [...] meningsuniverset, og det er til syvende og sidst også velbegrundet i en kultur, der som vor hviler på logos, ratio og intellekt [...]: først når vi er trængt ind i tekstens meningsunivers, forstås, hvilken betydning der kan ligge i nogle af dens lydvirkninger" (s. 8081). „Den fuldstændigste Falliterklæring“, fristes man til at gentage - også selvom Nøjgaards forklaring måtte have noget på sig.

Det er en brist over for en fundamental egenskab ved det lyriske digt, som man først for nylig er begyndt at spekulere over igen, og som disse sider ikke kan løse. I stedet vil jeg, efter denne indledende pointering af lyrikanalysens svage punkt, spørge bredere til det lyriske digts særpræg. Hvad skal en lyrikanalyse særligt besinde sig på? Et passende udgangspunkt kunne være en kort karakteristik af det lyriske digt.

\section{Det lyriske digt}

En minimal definition af et lyrisk digt kunne være, at det er en kort skønlitterær tekst på vers. Nøgleordene er kort og vers. Alle digte er på vers, lyriske digte er til og med korte. Verset er en au- 
dio-visuel enhed, det er rytmisk organiseret og kan kendes på sin løse højrekant. I verset er der mere og en anden opmærksomhed på ordene, bibetydninger myldrer, og udtrykket får betydning. Det sidste gør tegnet tendentielt motiveret. Vers står i en strofe, 'stanze' på italiensk. Det betyder værelse. Det lyriske digt er et lukket rum, det er i høj grad autonomt. En kort tekst aftvinger ordene alle deres betydninger, ikke mindst de, der skabes i forhold til de andre ord i teksten. Henvisningen smuldrer. Den er typisk tættere organiseret i troper og figurer, ikke mindst rytmiske og klanglige figurer. At bestemme det lyriske som andet end kort og hvad deraf følger kræver en læser. Den korte tekst på vers er et praj, der udløser en genrekompetence. ${ }^{7}$ Den kan gå ud på, at det lyriske digt er et jegs i tid og rum løsrevne monologiske tale, mest om sig selv, og reflekteret i omverdenen, typisk i naturen eller det andet køn. ${ }^{8}$

Allerede dette lille forsøg på at karakterisere det lyriske digt peger på tre primære særpræg: musik (versets auditive organisering, de rytmiske og klanglige figurer), billede (versets visuelle organisering, troperne) og konnotation (versets anden og korthedens mere koncentrerede opmærksomhed på ordene). Det er særpræg, som en lyrikanalyse selvklart bør iagttage, og som jeg vil uddybe i det følgende. Det sker med to beslægtedetekster om lyrik, en af Ezra Pound og en af Northrop Frye, og med to på sæt og vis modsatte kærlighedsdigte, et af Brorson og et af Henrik Nordbrandt.

\section{Pound og Frye}

I sit essay "How to read" tre slags poesi („Poetry“). Det er et lapidarisk, selvforelsket og didaktisk essay, som kun Pound gør det:

If we chuck out the classification, and if we look at what actually happens, in, let us say, poetry, we find that the language is charged or energized in various manners.

That is to say, there are three 'kinds of poetry': 
MELOPOEIA, wherein the words are charged, over and above their plain meaning, with some musical property, which directs the bearings or trend of that meaning.

PHANOPOEIA, which is a casting of images upon the visual imagination.

LOGOPOEIA, 'the dance of the intellect among words', that is to say, it employs words not only for their direct meaning, but it takes count in a special way of habits of usage, of the context we expect to find with the word, its usual concomitants, of its known acceptances, and of ironical play. It holds the aesthetic content which is peculiarly the domain of verbal manifestation, and cannot possibly be contained in plastic or in music. It is the latest come, and perhaps most tricky and undependable mode. (s. 25)

De græske ord kan oversættes til musikpoesi (egnt. sangpoesi), billedpoesi (egnt. synspoesi) og ord- eller tankepoesi. Alle tre er ekstra ladede. I den forbindelse siger Pound om forholdet poesi og prosa, at "The language of prose is much less highly charged, that is perhaps the only availing distinction between prose and poetry" (s. 26). Dog evner prosaen over en større mængde af ord at efterlade et tilsvarende ladet indtryk. Prosateksten er ikke mindre ladet end den poetiske tekst, det er det enkelte ord i prosaen, der er mindre ladet end det enkelte ord i poesien.

Musikpoesi underordner eller undgår den denotative betydning. Ordets udtryk bliver i stedet bærer af dets indhold. Tegnet er motiveret. Derfor er musikpoesi uoversættelig, mener Pound. Billedpoesi reflekterer billeder på fantasiens lærred. Den er forholdsvis oversættelig, da billeder kan flyttes fra et sprog til et andet. Ord- eller tankepoesi er konnotativt kalkulerende, den udforsker ordenes fjerne indhold, og er i modsætning til de to andre semantisk i sin kerne. Den lader sig heller ikke oversætte, omend "the author's state of mind" (s. 25) måske kan ekvivaleres eller afledes $i$ et andet sprog. Al litteratur er gjort af de tre slags plus et samlende fjerde: "plus 'arcitectonics' or 'the form of the whole'" (s. 25). Lige så meget som tre slags poesi er de ingredienser $i$ al poesi. Der er et sammenfald mellem Pounds 'arcitectonics' og 'stanze'. De er begge det lukkede rums metaforer, og som sådan om en radikal autonomi i poesien. Pound uddyber begre- 
berne, men taber de første formuleringers almene sigte. Så jeg står af her.

I Northrop Fryes ambitiøst-ironiske bogføring af litteraturvidenskaben, Anatomy of Criticism, 10 findes tilsvarende tanker om lyrik (,the lyric“). Frye bestemmer lyrik ved det, det grænser op til eller forsvinder i: musikken og billedet.

Også Frye griber tilbage til melos og udtrykket 'ta mele', som han først oversætter konventionelt som "to be sung" og siden som "to be chanted" (s. 273), med tanke på W. B. Yeats' udtryk 'cantillation', der betyder noget i retning af 'messen'. Oversættelse nummer to peger det, Frye kalder den orakliske rytme, ud. Den svarer stort set til Vedels meningsrytme, derfor min forlods brug af ordet. Den orakliske rytme er, ifølge Frye, lyrikkens fremragende rytme. Han kalder den også med afsnittets titel „The Rythm of Association". Den er en tale på kanten af det ubevidste, et musikalsk associativt kaos i slægt med drømmen, som i lyrikken finder sin form og dermed "the distinctive lyrical union of sound and sense" (s. 272). Det frie vers er ikke fri for rytme, men en befrielse af rytme, nærmere bestemt en befrielse af den orakliske rytme - jf. mine bemærkninger i forbindelse med Vedel. I sunget lyrik forsvinder den orakliske rytme, 'cantillation' derimod "is an emphasis on words as words" (s. 273). Madrigalen er det ekstreme udtryk for ordets forsvinden i musikken. I den er ordet underlagt musikkens variation og gentagelse, det er reduceret til tone, og således ramt på sit indhold. Det er sound, men ikke sense.

Lyrikkens anden grænse er billedet. Strofen er en visuel form, som skal udfyldes. Der er i det hele taget en høj grad af visualitet i lyrik. Den er organiseret i strofer og (fra og med renæssancen) beregnet til stillelæsning. Billedet er ikke kun digtbillede, men i højeste grad også billedsprog: „In any case there are thousands of lyrics so intently focussed on visual imagery that they are, as we may say, set to pictures" (s. 274). Ordet eller bogstavet som billede er det ekstreme udtryk for ordets forsvinden i billedet. Jeg kan nævne Apollinaires Calligrammes eller middelalder-manuskripternes dekorerede bogstaver. Frye taler her som Pound om opsis. 
Lyrikken formes på grænsen mellem det bevidste og det førbevidste til melos og opsis. De formende kræfter, forformerne til melos og opsis, kalder Frye babble og doodle, pludren og krusseduller.

In babble, rhyme, assonace, alliteration, and puns develop out of soundassociations. The thing that gives shape to the associating is what we have been calling the rhythmical initiative, though in a free verse poem it would be rather a sense of the oscillations of rythm within the area which gradually becomes defined as the containing form. (s. 275)

Babble er klang- og rytmefigurer i det førbevidste, som går forud for betydningen. Frye er mest optaget af rytmen. Ordspillet Frye taler senere mere smalt om paranomasia - er typisk for babble. Det balancerer mellem "verbal wit and hypnotic incantation" (s. 276). Som en førbevidst kortslutning i sproget pirrer ordspillet tanken, og udgør som sådan en dobbelthed af intellekt og sanselighed, distraktion og absorbtion. Som babble kan udfylde en rytmisk form, verset, udfylder doodle en grafisk: strofen. Frye er ikke så udførlig, hvad angår opsis.

Er babble og doodle forformer til melos og opsis, så er charm og riddle deres ekstremer - en finkløvning, der næppe er tjent med overdreven reverens:

The radical of melos is charm: the hypnotic incantation that, through its pulsing dance rhythm, appeals to involuntary physical response, and is hence not far from the sense of magic, or physically compelling power. The etymological descent of charm from carmen, song, may be noted. (s.287)

... the radical of opsis in the lyric is riddle, which is caracteristically a fusion of sensation and reflection, the use of an object of sense experience to stimulate mental activity in connection with it. Riddle-was originally the cognate object of read, and the riddleseemsintimately involved with the whole project of reducing language to visible form, a process which runs through such by-forms as hieroglyphic and ideogram. (s. 280) 
Charm forklarer sig selv. Riddles blanding af abstrakt og konkret kan f.eks. være abstraktets genitiv (f.eks. „syndens blomster“), eller katakresens tilsvarende sammenstilling af det usammenstillelige og derfor gådefulde (katakrese som uforenelighed mellem sags- og billedled i et billede eller indbyrdes uforenelige billeder). Riddle er altså et tropisk fænomen.

Fryes begreber er provisoriske og ikke helt adskillelige. Hans psykoanalytiske hang indsnævrer det almene i hans karakteristik, og begreberne udvikles i skæve og krydsende baner; men undervejs er der megen indsigt. Frye taler om lyrikken som grænsested og forsvindingspunkt, og har mindre begrebsligt blik for dets midte, det Pound kalder logopoeia, og som jeg vil kalde logos. Men logos findes også hos Frye, nemlig som det, det lyriskes pludren og krusseduller fører frem mod: "the distinct union of sound and sense". Det er tydeligt i talen om "words as words", der ganske vist sigter på at beskytte den orakliske rytme mod musikkens, men i princippet trækker en linie mellem musikken, og det Pound kalder "the domain of verbal manifestation". Logos ses også i ordspillets dobbelte karakter af vid og sanselighed. Et ordspil fører fjernt indhold sammen via ens udtryk: det er et kors for tanken. Heri ligner det riddle, der som intellektuel gåde også er et anliggende for logos. I sine grænseegne riochetterer det lyriske tilbage til det specifikt sproglige; men melos og opsis kaster det ikke tilbage til denotationen og henvisningen. Charm og riddle er associative mønstre af sløret eller potenseret betydning, deres . logos er som Pounds konnotativ. 11

Pounds og Fryes overvejelser bekræfter den indledende karakteristik af det lyriske digt. Dets særpræg er altså mindst tre: 1) melos, nærmere bestemt rytme og klang; 2) opsis, nærmere bestemt digtbillede og billedsprog; 3) logos, nærmere bestemt konnotation. Opfattet som vinklerne i en ligesidet trekant er de de yderpunkter, dét lyriske digts søger ud imod på vej væk fra midten, som er denotation, henvisning og tema: Logos med stort L. Nogle digte søger længere væk end andre, nogle mere mod nogle vinkler end andre. Kun de færreste, måske ingen, forlader midten aldeles. ${ }^{12}$ 


\section{Brorson og Nordbrandt}

Da der her er tale om forsøgvis at tænke det lyriske digts særpræg, vil jeg ikke føre tre eksemplariske digte som vidner, og slet ikke gøre eksemplariske analyser. Jeg vil begrænse mig til at anskueliggøre Fryes tredobbelte begrebspar med et digt af Brorson og et af Henrik Nordbrandt.

Brorsons Hvad est du dog skiøn, ja skiøn fra Svanesang13 (1765) er umiddelbart en eksemplifikation af charm som ,the radical of melos". Bruden/Sulamith/sjælen taler i strofernes to første vers, brudgommen/Salomon/Jesus i de to sidste:

XXXI.

Hvad est du dog skiøn, ja skiøn, Ja skiøn, du allerlifligste Guds Søn!

Du min Sulamith, Sulamith. Ja mit, Ja mit, alt, hvad jeg har, er ogsaa dit.

Min Ven, du est min, ja min, . Ja min; saa lad mig altiid være din!

Ja vist, ævig vist, ævig vist, ja vist!

Ja vist! du min skal blive her og hist.

Men tænk, jeg er her, ja her, Ja her iblandt saa mange dragne Sverd'!

Saa kom Due! kom Due! kom, ja kom!

Ja kom! I Klippens Rif er Roe og Rum.

Der er en excessiv brug af exclamatio (udråb) og gentagelse. Gentagelserne kan være variationer som første-versenes „dog skiøn, ja skiøn,/ Ja skiøn"; ,est min, ja min,/ Ja min "; ,jeg er her, ja her,/ Ja her" eller tredje-versenes kiasme „Du min Sulamith, Sulamith. Ja mit"; ,JJa vist, ævig vist, ævig vist, ja vist!“; ,Saa kom Due! kom Due! kom, ja kom!“. En tredje gentagelse er enjambementerne med efterfølgende cæsur mellem første og anden og tredje og fjerde vers. Stroferne er minutiøst ens opbyggede, og det er den fjerde vigtige gentagelse. Dialogens skift, rimene og de genkomne ord er atter andre mønstre af gentagelse. Til gengæld hersker der en for Brorson usædvanlig metrisk utakt. Sjælens læng- 
sel er udtrykt i en rytmisk uro, der slår sig mod de tætte mønstre af gentagelse. Mønstrene kan tolkes både som jordisk fængsel og som himmelsk ro. Gentagelsens figurer ligger som en form, ordene skal fylde, en, der går forud for ordenes indhold. Ordene tappes for betydning i den for vidt drevne gentagelse. ${ }^{14}$

Samme virkning har exclamatio, her som anråbelsens tomme figur. Dens udråbstegn står der, hvor verset ender, og skiller ord og tavshed. Digtet er en henført tale i hvilken ordenes betydning er forsvindende, de er blot markører af et møde på grænsen mellem det hypersanselige og det oversanselige. De talende er blinde som forelskede, og deres tale er tom. Babble, charm, 'cantillation' er alle passende udtryk for Brorsons melos her - og andre steder i Svanesang.

I versene er den dominerende vokal grafisk set et omvendt udråbstegn: i. Som sådan forstærker det den i forvejen dominerende exclamatio. Klangligt giver i'erne digtet en opadsøgende skinger tone: de skriger mod himlen, som exclamatio også gør her. Forløbet af i'er er sådan her: skiøn skiøn skiøn lifligste min mith mith mit mit dit// Min min min min mig altiid din vist ævig vist ævig vist vist min hist// iblandt I Klippens Rif. Det giver tematisk mening, idet det beskriver en transcendens. Fra det sanselige (skøn og liflig) går det via en intens genitivisk udveksling mellem mit og dit, hvor de talende tager hinanden $i$ besiddelse - $\mathrm{i}$ et omfang så hendes navn invaderes i spillet mellem "mit" og -"mith" - til vished om evigheden (altid og evig vist) i det hinsides (hist). Den skingre, udråbende vokal finder til sidst hvile „I Klippens Rif”, dvs. i Jesus' sår. Højsangsduen søger skjul $i$ en klipperevne. Det bliver i allegoresen af Højsangen et billede på Jesus' sidesår, hvor sjælen er beskyttet. I sidste vers afløses i'erne af de bredere og dybere vokaler; i'et i „Rif” føres allitererende mod "Roe og Rum", samtidig med at jamberne, der har levet en ustadig tilværelse digtet igennem, her er uantastede. Rytmisk og klangligt er der ro; og det snævre - grafisk og klangligt set i de smalle og skape i'er, særlig tydeligt i forhold til „oe” og "u”, og billedliggjort af „iblandt saa mange dragne Sværd” - er afløst af et uendeligt himmelsk rum. 
Der sker imidlertid et skift til sidst fra melos til opsis. Det i strofe et og to billedløse digt får i tredje strofe først metaforen "dragne Sverd" for det for sjælen pine- og farefulde jordeliv og slutter med det for en moderne læser chokerende slutbillede af den frelste brud i Jesus' sår. Den teologiske logik, at frelseren ved sine lidelser udfrir menneskeheden, får i sin poetiske udmaling en sanselig påtagelighed, der for alle andre end 1700-tallets hernhuttiske pietister bliver en dissonans af salighed og frelse og blod og sårvæske. For de fleste læsere fastholdes digtet som en kollision af hypersanseligt og oversanseligt. Den himmelske fred, der sænker sig til sidst, står i længslens og ikke opfyldelsens tegn. I'erne harmoniseres i den afsluttende akkord, men den fredfyldte melos er her underordnet en dissonantisk opsis, hvis riddle er digtets slutpunkt. Resultatet er en opsis, der er lige så outreret som digtets melos. ${ }^{15}$

Henrik Nordbrandts Violinbyggernes by ${ }^{16}$ fra samlingen af sammen navn udgivet i 1985 er umiddelbart et eksempel på riddle som "the radical of opsis".

Violinbyggernes by

Hver gang du kommer tilbage

kunne jeg dræbe dig for det

- af misundelse over den udsigt

jeg ikke fik set, floden

der slyngede sig gennem byen og ud

$i$ et blomstrende landskab

med mindre det er en strøm af blå heste

bjergenes sne og de indfødtes

sprog, de indforståede vittigheder

de fortalte om deres konge.

"Violinbyggernes by" har jeg ofte

døbt det sted, hvor jeg leder

efter din sjæls foretrukne tilholdssted

din melankolis skovbund, og den særlige

tone i lyset over din kind

den som gør mig gal sidst på vinteren

eller med andre ord: Om døden ved jeg intet

men en sådan afmagt tillægger jeg de døde

en sådan genstandsløs længsel

at intet billede kan gøres 
på trods af rammen, som altid er der:

Hele natten ned ad floden

lå vi ikke desto mindre vågne på dækket

og lyttede til strygermusikkender

blev båret ud mod os fra usynlige bredder.

Kvinden står i vejen for sine metaforer. „den udsigt, jeg ikke fik set" er ikke bare en udsigt, men en række overførte billeder, samlet i, hvad der derfor er, symbolet „Violinbyggernes by“. Der søger jeg'et hendes „sjæls foretrukne tilholdssted“. Hendes nærvær er skyld i et metaforisk fravær og med det en blindhed for hendes væsen. Men hun står kun i vejen for sine metaforer $i$ to vers, eller sagt på en anden måde: digtet er en spejlvending af sit eget indledende udsagn; $i$ digtet står metaforerne $i$ vejen for kvinden, hun er kun metaforisk tilstede $\bar{i}$ det.

Forholdet mellem de enkelte passager er uafgørligt. Det gælder mellem digtets to sætninger og i den sidste sætnings deling $i$ tre ved kolonnerne, der formelt er underordnende, men reelt sideordnende. Dèt gælder også de overgange, der sker ved de beslægtede udtryk "med mindre", "med andre ord“, ,,ikke desto mindre“. De er korrigerende skift i tanken, en evig tænken om igen. Digtet er en arabesk, hvor billeder og refleksioner slynger sig uafgørligt ind og ud mellem hinanden i gentagne forsøg på at fatte hende. Den syntaktiske rytme er den dominerende. Den slynger sig som en flod nedefter i en hypotakse, der bl.a. er markeret ved kolonnerne og de nævnte udtryk. Alt i alt opstår en dissonans mellem et analytisk eller diskursivt sprog og den billedlige associeren. Forelskelsens inderlige fortabelse er udtrykt i en pointeret tom kølighed.

Udsigten er til et blomstrende flodlandskab, „med mindre“ den er til "en strøm af blå heste" og et mere fremmed og vinterligt landskab. Dette landskab er måske stedet for violinbyggernes by. Han søger efter hende i det, han har døbt violinbyggerens by, og han gør det på kanten af klichéen med to abstraktets genitiver og en synæstesi: "din sjæls foretrukne tilholdssted", "din melankolis skovbund", ,"tone i lyset over din kind“. Begge måder 
har katakresens effekt - jf. Frye om abstraktets genitiv og katakrese som riddle-træk-idet de sammensætter hhv. konkret og abstrakt og lyd og syn. Forholdet mellem dem, skabt af springet mellem de to førstes indre beskrivelse (sjæl og melankoli) og den sidstes ydre (kinden), er tilsvarende katakresisk. Et spring mage til ses fra det lydhørt intime "foretrukne", og "skovbund"s sanseliggørelse af melankolien i bløde og våde efterårsblade, til senvinterens hårde lys og ordet "gal“. Ordet står kort og godt blandt andre småord, hvor versene forinden består af lange, tunge romantiske ord. Passagen springer mellem kliché og inderlighed. Således konnoterer det lille ord "døbt" både nominalistisk vilkårlighed og rituel kærlighedshandling. Det er en samtidighed af retorisk skin og forelsket billedlig afsøgning af sjælen, som fastholder det indledende hverken-eller mellem kvinden og metaforerne.

"Eller med andre ord", hedder det så. Døden, der her dukker op igen, afsætter en følelse hinsides metaforen: „med andre ord [...] intet billede“. En billedløs refleksion afløser billederne i dette afsnit, men kun for at sige, at billedet intet kan sige. Det, der i forvejen ikke kunne ses, men alligevel blev gjort, mest intenst i den billedlige eftersøgning inden kolonnet, kan ikke gøres. „ikke desto mindre" gøres det igen. Det giver et fordoblet paradoksalt forløb fra udsigten, der ikke kan ses, men alligevel beskrives, til billedet, der ikke kan gøres, men alligevel gøres. Floden kommer igen, og de to, der før hhv. spærrede for den og ikke kunne se den, er nu i den. Metaforens skaber og hans sagsled, kvinden, er begge til stede i billedleddet til sidst. ${ }^{17} \mathrm{De}$ er blevet ét med deres metaforer og for så vidt formelt forenede. Og digtet toner ud. Det er, på udsigelsens niveau en metaforisk og på temaets en musikalsk apoteose: de elskende bæres bort på melos og opsis.

Blot er blindheden, på det tematiske niveau, konstant og konstant æggende. Fra de usynlige bredder kommer strygermusik, måske fra violinbyggernes by, der i så fald må være i nærheden og dog er fjem. Udgangen opretholder et status quo i forhold til digtets begyndelse, hvor udsigten lå for, men udsynet var spærret. Modsat Brorsons digt afløser melos opsis hos Nordbrandt; øjnene ser til sidst intet, men ørerne hører. Den tropiske drøm til 
strygermusik båret fra bredder er nærved at være paradisisk. Det svarer til den metaforiske og musikalske ophævelse, men ikke til at scenen læst i digtets sammenhæng stadig er om blindhed. Til det lægger sig konnotativt skibet som skibe i natten, en død metafor, Nordbrandt ofte bruger.

Paradokserne er potenseret noget nær i n'te. Diskursen er sprængt - så meget desto tydeligere ved på skrømt markeringer som de sammenbindende udtryk, kolonnerne og den hypotaktiske syntaks. Det er et billedrigt digt om blindhed. Digtets billeder er afmægtige, men de gøres alligevel. Til slut er metaforen ophævet og med den enhver forskel, også mellem de elskende, hvis verden opløses i musik. Alligevel er blindheden konstant. Digtet træder som suggestiv væren på klassisk modernistisk vis i stedet for verden; men verden træder også ind foran digtet. De skygger for hinanden, som kvinden står i vejen for sine metaforer, og metaforerne på udsigelsens niveau står i vejen for hende. Udsigelse og tema krydses i en rebussens paradoksi, en suggestiv gåde, hvis løsning er, at der ingen løsning findes, og dog; at enhver tilnærmelse skyder sin genstand fra sig, og alligevel ikke. Det er ikke bare riddle, det er også doodle, en billedlig tale i en nedbrudt diskursivitet, uigennemsigtigt og sammenfiltret: krusseduller, eller mere respektabelt og stadig med en visuel metafor: arabesk.

Digtet udtrykker en med nødvendighed rastløs modus vivendi mellem sprog og verden. Det er det, der ses i det fortættede billedlige passages dobbeltbund af retorik og inderlighed, i dissonansen mellem den tøjlede syntaktiske rytme og den frie billedlige associeren og i det uophævelige hverken-eller mellem kvinden og metaforerne. Violinbyggernes by er en billedets og kærlighedens apori, båret frem af en tro på begge dele. 


\section{Noter}

1. Jf. Jørn Erslev Andersen: "Sonetinske digressioner", in: Arbejdspapirer, Institut for Litteraturhistorie, Aarhus Universitet, for tilsvarende betragtninger.

2. Valdemar Vedel: "Meningsrytme”, in: Edda bind XII, 1919-20.

3. Poul Borum: „Meningsmetrik”, in: Kritik nr. 9, 1969. Se også Kritik nr. $2 \operatorname{og} 3$.

4. Borum forsøger i sin artikel af føre principperne ud i livet, og jeg har forsøgt at benytte mig af ideen i min analyse af Den store Rhytme, in: Dan Ringgaard: Striden og skønheden. Analyser i Sophus Claussens lyrik, Århus 1994, 56-58.

5. Denne tredeling i metrisk, oraklisk og prosodisk rytme bekræftes indirekte, hvis man lægger to nyere danske bidrag om metrik over hinanden. Thorkild Bjørnvig taler i sit essay "Rytmen og metret", in: Barlyng (red.): I kentauerens tegn, Haslev 1993, om det mekaniske meter kontra hjertets rytme. Det er stort set en skelnen mellem metrisk og oraklisk rytme. Per Aage Brandt skelner i “Hvad er metrik?”, in: Passage nr. 16, 1994, mellem det numerisk organiserede og det emfatisk organiserede, altså mellem metrisk og prosodisk rytme. Se også Brandts "Metriske meditationer", in Passage nr. 11/12, 1992.

6. Morten Nøjgaard: Det litterære værk, Odense 1993.

7. Jf. Stanley Fish: „How To Recognize A Poem When You See One", in: Is there a Text in this Class, Cambridge Mass. og London, 1980.

8. En yderligere kvalifikation af karakteristikken kan slå sig på troper og figurer; der forekommer ofte og centrale i det lyriske digt. Cleanth Brooks foreslår prøvende i The Well Wrought Urn, New York 1947, paradokset som indbegrebet af det poetiske sprog. Som noget, der taler imod og ved siden af vane og vedtægt, genaktualiserer paradokset det kendte ved at sprænge konventionen og oplyser underet. Jonathan Culler foreslår med tilsvarende forsigtighed i artiklen "Apostrophe”, in: The Pursuit of Signs, London 1981, apostrofen, som det lyriskes mesterfigur, som det uassimilerbare, der hvor sproget ikke er meddelelse, men handling. Det lyriske i sin essens altså, som hhv. para-doxa og anti-logos.

9. Ezra Pound: "How to Read", in: Literary Essays of Ezra Pound, (T.S. Eliot, red.), Oxford 1963.

10. Northrop Frye: Anatomy of Criticism, St. Ives plc, 1990 (1957), 270-81. 11. I sin oversigt over lyrikanalysen siden nykritikken, "Changes in the Study og the Lyric", in: Hosek og Parker (red.): Lyric Poetry beyond New Criticism, Ithaca N.Y., 1985, relancerer Jonathan Culler Fryes babble og doodle, og mener at finde en øget interesse for det, de står for. I samme bog findes et mindre omfattende bud på, hvad lyrik er fra Northrop Frye: "Approaching the Lyric". 
12. Udfordringen for lyrikanalysen er som sagt melos, hvorimod den del af opsis, der er billedsproget, trives. Melos' anden halvdel, klangen, er om muligt endnu vanskeligere at kvalificere ud over det deskriptive end rytmen. Det bedste bud, jeg kender, er Roman Jacobsons arbejder, navnlig bogen The Sound Shape of Language (med Linda R. Waugh), Bloomington 1979. Jacobson står i sin tur i gæld til den russiske formalismes interesse for området. Hvad angår logos ligger det for at pege på Roland Barthes' S/Z, Paris 1970, og inden for lyrikanalysen er Michael Riffaterres Semiotics of Poetry, Bloomington 1984 (1978) oplagt. Udfordrer Barthes grænscrne for fortolkning, så er Riffaterres 'superreader' interesseret $i$ at udtømme konnotationerne inden for denne grænse. For begrebet 'superreader' se Michael Riffaterre: „Describing Poetic Structures: Two Approces to Baudelaires "Les Chats", in: Tompkins (red.): Reader-Response Criticism. From Formalism to Post-structuralism, Baltimore 1980. Borums "Meningsmetrik" (note 3) og Cullers "Changes in the Study of the Lyric" (note 11) indeholder i øvrigt adskillelige anvendelige litteraturhenvisninger.

13. H. A. Brorson: Udvalgte salmer og digte, Holstebro 1994.

14. Jf. Steffen Arndal: „Den store hvide flok vi see...”. H. A. Brorson og tysk pietistisk vakkelsessang, Viborg 1989, 352-53, navnlig for det metriske.

15. Hertil kommer, at allegoresens brud og brudgom i forvejen kræver sit af den mandlige læsers indbildning. F. J. Billeskov Jansen gør sig i Danmarks Digtekunst II, Kbh. 1947, 104-5, nogle betragtninger om forholdet mellem teologisk og poetisk allegori og om højsangsallegoresens kønslige identifikationsproblemer.

16. Henrik Nordbrandt: Violinbyggernes by, Haslev 1985.

17. Thomas Bredsdorff bemærker dette træk ved Nordbrandts metaforik og viser, hvor udbredt det er i forfatterskabet i Med andre ord. Om Henrik Nordbrandts poetiske sprog, Haslev 1996. Bredsdorff behandler digtet på siderne 128-30. 